\title{
Mate Choice in Human
}

\author{
Fatik Baran Mandal
}

Department of Zoology, Bankura Christian College, Bankura, Pin: 722101, India

\begin{abstract}
The ultimate aim of human survival is propagation of DNA through reproduction and to enhance the fitness. Reproduction requires mates and sex. Human mate choice is complicated because a combination of influences always works. Men prefer young women with a low waist-to-hip ratio and are more interested in short-term casual sex than women. A man's mate value depends on his wealth, status, and power whereas a woman's mate value is influenced by her youth and physical attractiveness. In humans, both sexes tend to be choosy .Facial symmetry, facial averageness, facial expression of sex hormone levels, and male upper-body musculature, function as fitness indicators. Average faces are attractive in males, but females with more neotenous faces, including large eyes, small noses, and full lips are more attractive. Males with testosterone-induced features such as high cheekbones, strong jaws, strong chins, and large noses are attractive. Similarities and dissimilarities in the mate choice of men and women are reviewed. Understanding the good gene based mate choice is yet to be conclusive. However, the indicators of mate choice have the genetic basis. Therefore, it seems probable that selection for genetic quality is the key criteria in human mate choice.
\end{abstract}

Keywords genetic quality, facial signals, beauty and intelligence, evolutionary perspective

\section{Introduction}

Attempts have taken to explain "why we behave the way, we do". Human behaviours often attract media attention. However, many aspects of human behaviour are controversial[1].Human behaviour is determined by a multitude of constantly changing and interacting variables. On a personal level, knowledge, attitudes, goals, power, and personality determine the individual's disposition toward performing certain behaviours[2].

Sexual selection occurs due to competition within each sex to attract sexual partners of the opposite sex[3]. Two kinds of sexual selection are aggressive rivalry and mate choice[4]. Rivalry between males produces weapons like sharp teeth. Mate choice by females produces ornaments like colorful tails. Darwin considered female mate choice in producing male ornaments. Biologists, after Darwin, emphasized on male rivalry, rejecting the possibility of female choice[3]. In sexual selection, competitive males struggle for possession of females by acquiring territories and status, and repelling rivals. Ornaments, the species-recognition signals, help animals to avoid mating with the wrong species. Sexual selection often produces sex differences, but not always. In humans, both sexes tend to be choosy, and evolve sexual ornaments[3]. Biological variables indirectly induce physiological, psychological, and social events which in teract with the cultural context and leads to sexual preferences[5]

* Corresponding author:

fatikspeaking@yahoo.co.in (Fatik Baran Mandal)

Published online at http://journal.sapub.org/ijpbs

Copyright (C) 2012 Scientific \& Academic Publishing. All Rights Reserved in human. The pairing process in human affect survival rates, population size[6], and the future of the human race.

\section{Mate Selection Indicators}

Such indicators are discussed under the following two heads:

\subsection{Fitness Indicator Theory}

Many sexually-selected traits like health and genetic quality are reliable indicators of mate choice[7]. These traits, called the fitness indicators, determine the individual's expected Darwinian fitness[3]. Choosing sexual partners with high fitness ensure high chances of transmitting good genes to the offspring. Indicators are costly for becoming reliable and are usually subjected to the 'handicap principle'[7]. Cheap, easy-to-grow and maintain indicators could be faked by unhealthy, unfit individuals and the indicator would lose its value as a signal, and receivers would ignore it. The indicator must have higher relative costs to an unfit animal than it does to a highly fit animal[8]. Handicap principle is a major theme in sexual selection research[9]. Vulnerable traits amplify the apparent variance in phenotypic quality across individuals[10]. Visible individual differences amplify the power of sexual selection to evolve ornament quality and fitness in mate choice[11]. Many cues of human physical beauty function as fitness indicators.

\subsection{Indicators of Genetic Quality}

Fitness indicators often advertise good genes. 'Good gene' shows a genotype with few expressed deleterious mutations 
for lowering fitness. Sexual selection for indicators of genetic quality is a major factor in long-lived species to persist in the face of mutation's entropic power[12]. The spread of harmful mutations may be limited by evolution of sexual reproduction[13]. Indicators of genetic quality can be bodily traits, or behavioral traits. Behaviours are often better fitness indicators because brains are the complex, hard to grow, costly to maintain, and easy to disrupt, compared to other organs[3]. Some behaviours show an individual's genotype depending on more complex neurogenetic developmental pathways[11]. As selection should have eliminated maladaptive genetic variation, it makes sense for traits that evolved under natural selection for survival, but they do not make sense for sexually selected fitness indicators[14]. To be reliable, fitness indicators must be difficult to produce for low-fitness individuals[8]. In most cultures "goodness and beauty are the same" [15]. Our sense of beauty has shaped by evolution to aware of what is costly versus cheap, and fit versus unfit. All animal signalling systems convey primarily the fitness information about the signaller[16].

Indicator for mate choice includes revealing age, health, nutritional status, size, strength, aggressive dominance, social status, disease resistance, or overall vigor[17]. Indicators advertise resources and health relevant to raising offspring, although always not advertise genetic quality. Females shape males to function as a genetic sieve [18], select those males with good genes, and ignore those with the bad. Moderate dimorphism occurs with intense sexual competition between males than between females[19]. Symmetry correlates with "developmental competence"- resistance to disease, injury, and harmful mutations that cause "fluctuating asymmetry" during development[20].

\subsection{Facial Signals}

Facial musculature is well-developed for displaying expressions[21]. Bilateral symmetry, average, and secondary sexual characters characterize attractive face[22]. Facial symmetry is a marker of health. Some individuals withstand stress and show less asymmetry. Humans prefer to mate people with symmetrical facial features. Asymmetric facial features are less healthy and less attractive[23]. Social judgment that makes from the faces is attractiveness. Greater exaggeration characterized symmetrical faces of robust and neoteny features. Facial asymmetry (FA) shows genetic disturbances and increases with exposure to environmental perturbations during development. Bilateral symmetry is related with heterozygosity and resistance to infection. Men with asymmetric faces and body features have higher basal metabolic rates, lower IQs, and fewer sexual partners than their more symmetric peers[24]. The relationship of symmetry, averageness and facial attractiveness, each of which may be attractive, as they are related to judgments of physical health, also known as the "good genes" approach [25]. This approach states that the attractive features represent freedom from parasites and infections. FA, hormone markers in the face, facial structure in general, and physical attractiveness are heritable[26].

\subsection{Beauty and Intelligence}

Beauty is an indicator of health. Physically attractive people are healthier than less attractive people[27]. Human perceives attractive others as more intelligent, good, competent in general and competent at specific task[28]. Men like young and attractive women, and women like rich and powerful men[29]. Infants (12-month old) play longer with facially attractive dolls than with unattractive dolls. Thus, judging the standard of beauty might be innate not learned[30] and is culturally universal and invariant[31]. FA of faces increases with exposure to toxins and genetic disruptions[32]. Individuals with attractive faces have less chance to be homozygous on deleterious alleles[33]. Skin tone and luminosity show a person's health ,reproductive capability and may be a major signal for mate selection, attractiveness and perceived ages. Women with hourglass figure are more fertile due to high female hormone level. Beauty blinds people[34]. Middle-class girls have higher IQs, and more attractive than working class[35]. In long term relationship, men prefer intelligent marriage partner[36]. Facial attractiveness significantly correlates with IQ among both men and women throughout the life course except late adulthood.

\subsection{Thinness and Fatness}

Female body fats have several fitness enhancing functions including insulation, storage of calories and fertility regulation[37]. Men with scarce resources prefer heavier women. Men with abundant resources prefer thinner women. Ugandan participants assign higher attractiveness ratings to more obese male and female than do British participants[38]. A direct relationship between socioeconomic status and female obesity rate in developing societies and an inverse relationship in developed nations is recorded[39]. Resource availability may be a driving force in determining mate preference[40].

\subsection{Waist -to- Hip Ratio}

Male preference for a Waist-to-Hip Ratio (WHR) is .70.The WHR of healthy, pre-menopausal women in developed societies typically ranges from .67 to $.80[41-43]$. Men prefer female figures that varied in both WHR and total amount of fat. Men find women with low WHRs the most attractive. Women with a .70 WHR are more attractive than women with .80 , who in turn is more attractive than women with .90 . However, every culture tested so far has been exposed to the potentially confounding effects of western media[44]. Wetsman and Marlowe[45] examined male WHR preferences in a foraging Hadza society and found that Hadza strongly preferred heavier women over thinner women, and they did not systematically prefer either a .7 0or $90 \mathrm{WHR}$. This suggests that mate preference could be sensitive to food scarcity. A low WHR woman is more fertile, which make them lucrative mates than high-WHR women. Body-weight-matched girls with lower WHR exhibit earlier pubertal endocrine activity, as measured by high levels of 
lutenizing hormone, follicle-stimulating hormone, and steroid activity. Married women with higher WHR and lower body mass index (BMI) reported difficulty in becoming pregnant. Their first live birth occurs at a later age than married women with lower WHR. Difference in WHR between women who did and did not face difficulty in becoming pregnant was 0.838 vs. $0.840[46]$. Difference in WHR between women who had their first live birth before 30 and those having their first birth after 30 was 0.838 versus 0.843 . Men are attracted to low waist-to-hip ratios in females, and a low female waist-to-hip ratio correlate with youth, fertility, and health[47].

\subsection{Social Status}

Higher status persons are generally taller than lower-status people. In the past, many competitions for status were the physical, although alliances and coalitions were also important[48]. Since 1776, only two U.S. Presidents were below average in height, and the taller candidate almost always wins the Presidential election[49]. Men who occupy higher status position are more intelligent. The U.S. Department of labor shows the following mean IQs for selected occupation engineer(130), accountant(118), teacher(114),bookkeeper (11 0 ), photographer(108),stenographer(106), machinist(104), car penter(99), laborers(92) and stock clerk(84)[50]. Among both black and whites, upwardly mobile women are more physically attractive than others[51]. General intelligence is largely heritable[52]. Women of higher socio-economic status could afford relationship with lower status males since they could provide resources, yet they increase their requirements. Cross-cultural study shows that sex difference with the emphasis on resource-acquisition characteristics diminish in gender-egalitarian societies[53]. This has been generalized that intra-culturally women's preferences for high status mates increase with their socio-economic structure[54].

\subsection{Other Criteria of Mate Choice}

Women, for marriage, prefer a man with a wide smile, small eyes, a big nose, and a large jaw which indicate a strong testosterone level. Distance from eyes to chin and size of lips shows female attractiveness. Immunocompetence directly related to immune gene (MHC) diversity is an important determinant of fitness[55]. For increasing immune gene diversity in offspring, individuals can mate promiscuously and choice mate[56]. Permanent enlargement of breasts and buttocks is effective at concealing ovulation[57]. Men with higher testosterone have more masculine faces. Higher androgen levels in men exhibit masculine features: taller, darker, more muscular, with lower pitched voices, and deposits of adipose tissue that increase the waist to hip ratio (WHR) compared to desirable females[41]. High estrogen levels in women cause large breasts and narrow waists[58], high pitched voices.

Physically appealing androgenic characteristics like height, darker complexion, and masculine facial features might explain a preference for a tall, dark, handsome, and dominant male, since these characteristics are associated with androgenic pheromones[59]. Women and men want intelligent, kind, understanding, dependable and healthy mates. Mutual attraction and love emerged as most valued qualities in a spouse[60]. Men ideally like 18 mate in their lifetime, whereas women average 4.5[61]. Hypotheses about benefits of women from short term mating are formulated[62]. Women rate the emotional stability and family orientation of prospective marriage partners more highly than do men[63]. They prefer men with who feel physically safe and protective for them[64]. Many women prefer men with who can develop an intimate and emotionally satisfying relationship (Buss, 1994). Women prefer taller men with an athletic and symmetric body shape and wider shoulders[63] and consider prominent cheek bone as this is related androgen/ estrogen ratios during puberty[65].

Most men want a long term marriage partner, and many women only want a long term partner[66]. Men are predicted to be nearly as choosy as women and show both similarities and differences in the criteria used to choose long term mate[67]. Women are attracted to a best combination of neonatous, mature and expressive facial features[68]. Such studies can be linked to power, status, maturity and sociability. Men and women having similar minds exhibit the mutuality in mate choice[69].

\section{Discussions}

Human mate choice is a product of evolutionary history and reflects the mechanisms that influenced the evolution and proximate expression of mate choices in other species [70]. Mate choice and attendant cognitions and behaviours of both sexes have evolved to exploit the reproductive potential and reproductive investment of the opposite sex. Individual mate value drives the dynamics of male-male and femalefemale competition for the best mates. It is biological and social evolutionary perspective that needs to be considered for understanding mate choice in human. Uniform rules for human mate choice appears to be lacking. Biologic- social-, cultural-, and economic- factors are involved in human mate choice. The ultimate aims of human survival are propagation of DNA through reproduction. Mating with unhealthy partner generally results in unhealthy offspring, while in a joint venture with an attractive high quality mate, high quality genes are much likely to be passed on. This is reflected when modern women choose their sperm donors very carefully.

The influence of human stature in mating pattern is known[72]. Females emphasize less on physical attractiveness than males[73]. Female preferences for stature and BMI are relatively good predictors of attractiveness[74]. Natural selection favors young intelligent males[75]. Sexual selection favors male leadership and tool making[76] and accounts for the evolution of language[77]. Warfare for possession of females and mating-relevant resources is a major force in human evolution[78]. Oratory as an arena of male competition is suggested along with its role in the evolution 
of language[79]. As females fitness is determined by their offspring's survival, female exhibits choosiness[80].

On a proximate level, they choice directly through preference or resistance,or indirectly through oestrus advertisement. On an ultimate level, females choose for direct benefit like paternal care or indirect benefits like 'good genes'[81]. Male reproductive success depends primarily on the number of females they can fertilize[82]. MHC constitution is an important factor that participates in mate choice decisions. The most important hypotheses explaining mate choice mechanisms are the disassortative mating hypothesis and the good-genes-as-heterozygosity hypothesis[55]. This hypothesis state that mate choice may function to avoid incompatibility between maternal and paternal genes or inbreeding and would lead to offspring being genetically different from each parent. As most indicators of mate choice have the genetic basis, it seems probable that genetic quality is central theme in mate choice in human. Preferences for sex partner in human male and female differ in key criteria with strong evolutionary significance. Age, physical attractiveness, resources or social skills may be important in mate choice[71]. Women pay much emphasis to commitment and resources[36].

\section{REFERENCES}

[1] Mandal, F. B, Textbook of Animal Behaviour (pp.xii, 302). New Delhi, India: PHI learning Private Limited, 2010.

[2] Mandal, F. B, 2011, Human behaviour and biodiversity loss: A theoretical Analysis. Journal of Human Behaviour in the Social Environment, 21, 601-605.

[3] Miller, G. F, The mating mind: How sexual choice shaped the evolution of human nature. New York: Doubleday, 2000a.

[4] Darwin, C, The descent of man, and selection in relation to sex (2 vols.). London: John Murray, 1871

[5] Bem, D. J. 2000. Exotic becomes erotic: interpreting the biological correlates of sexual orientation. Archives of Sexual Behavior, 29, 531-548.

[6] Quader, S. 2005. Mate choice and its implications for conservation and management, Curr. Sci, 89, 1220-1229

[7] Zahavi, A.and Zahavi, A, The handicap principle: a missing piece of Darwin's puzzle. Oxford University Press, Oxford. , 1997.

[8] Grafen, A, 1990, Biological signals as handicaps. J. Theoretical Biology, 144, 517-546.

[9] Johnstone, R. A, 1995, Sexual selection, honest advertisement and the handicap principle, Biological Review, 70, 1-65.

[10] Hasson, O, 1990, The role of amplifiers in sexual selection: An integration of the amplifying and Fisherian mechanisms. Evolutionary Ecology, 4, 277-289.

[11] Houle, D. Is there a g factor for fitness? In G. Bock, J. A. Goode, \& K. Webb (Eds.), The nature of intelligence, No- vartis Foundation Symposium, 233 (pp. 149-170). Chichester, UK: John. Wiley, 2000.

[12] Rowe, L., \& Houle, D, 1996, The lek paradox and the capture of genetic variance by condition dependent traits. Proc. R. Soc. London B, 263, 1415-1421.

[13] Ridley, M, The red queen: Sex and the evolution of human nature. New York: Viking, 1993.

[14] Miller, G. F, Mental traits as fitness indicators: Expanding evolutionary psychology's adaptationism. In D. LeCroy \& P. Moller (Eds.), Evolutionary perspectives on human reproductive behavior, Annals of the New York Academy of Sciences, Volume 907 (pp. 62-74). New York: New York Academy of Sciences. 2000b

[15] Boas, F, Primitive art. New York: Dover, 1955.

[16] Bradbury, J. W., \& Vehrencamp, S. L, Principles of animal communication, Sunderland, MA: Sinauer, 1998.

[17] Miller, G. F, How mate choice shaped human nature: A review of sexual selection and human evolution. In C. Crawford \& D. Krebs (Eds.), Handbook of evolutionary Psychology, Crawford, C. \& Krebs, D. L. ( Eds), pp.87-129, New Jersey, : Erlbaum, 1998.

[18] Atmar, W, 1991, On the role of males. Animal Behavior, 41, 195-205.

[19] Martin, R.D., Willner, L.A., \& Dettling, A, The evolution of sexual size dimorphism in primates. In, R. V. Short \& E. Balaban (Eds.) The differences between the sexes (pp. 159-200), Cambridge University Press, 1994.

[20] Thornhill, R. \& Gangestad, S. W, 1999, The scent of symmetry: A human sex pheromone that signals fitness. Evolution and human behavior, 2, 175- 201.

[21] Darwin, C, The expression of the emotions in man and animals, Appleton (Volta), London, 1872.

[22] Little, A. C., Penton-Voak, I. S., Burt, M., \& Perrett, D. I, Evolution and individual differences in the perception of attractiveness: How cyclic hormonal changes and self-perceived attractiveness influence female preferences for male faces. In G. Rhodes \& L. A. Zebrowitz (Eds.), Facial attractiveness: Evolutionary, cognitive and social perspectives (pp. 59-90). Westport, CT: Ablex, 2002.

[23] Buss, D. M, Evolutionary psychology: The new science of mind. New York: Allyn \& Bacon, 1999.

[24] Manning, J. T., Scutt, D., Whitehouse, G. H., \& Leinster, S. J, 1997 ,Breast asymmetry and phenotypic quality in women. Evolution and Human Behavior, 18, 1-13.

[25] Rhodes, G., 2006, The evolutionary psychology of facial beauty. Annual Review of Psychology, 57, 1

[26] Kanazawa, S., Kovar, J.L. 2004. Why beautiful people are more intelligent. Intelligence 32, 227-243.

[27] Webster, Jr,M.\& Driskell, Jr J.E,1993,Beauty as status. American Journal of Sociology, 89,140-165.

[28] Buss, D.M, The evolution of desire: Strategies of human mating, New York: Basic Books, 1994.

[29] Langlois, J.H. \& Roggman, L.A, 1990, Attractive faces are also average, Psychological Science 1, 115-121. 
[30] Cunningham, M.R., Barber, A.P.\& Pike, C.L, 1990, What do women want? Facimetric assessment of multiple motives in the perception of male facial physical attractiveness, Journal of personality and Social Psychology, 59, 61-72.

[31] Parsons, P. A, 1992, Fluctuating asymmetry: A biological monitor of environmental and genetic stress. Heredity,68, 361-364.

[32] Thornhill, R.\& Gangestad, S. W, 1993, Human facial beauty: averageness, symmetry and parasite resitance, Human Nature, $4,237-239$.

[33] Kalick, S.M., Zebrowitz, L.A., Langlois, J.H., and Johnson, R.M, 1998, Does human facial attractiveness honestly advertise health: Longitudinal data on an evolutionary question. Psychological Science 9,8-13.

[34] Elder, Jr G.H, 1969, Appearance and education in marriage mobility. American Sociological Review, 34, 519-533.

[35] Li, N. P., Bailey, J. M., Kenrick, D. T., and Linsenmeier, J. A. W, 2002, The necessities and luxuries of mate preferences: Testing the tradeoffs. Journal of Personality and Social Psychology, 82, 947-955.

[36] Anderson, J. L., Crawford, C. B., Nadeau, J., and Lindberg, T. 1992, Was the Duchess of Windsor Right? A Cross-Cultural Review of the Socioecology of Ideals of Female Body Shape, Ethology and Sociobiology, 13(3), 197-227.

[37] Furnham, A. \& Bagume, P, 1994, Cross cultural differences in evaluation of male and female body shapes. International Journal of eating Disorders, 15, 81-89.

[38] Sobal J and Stunkard AJ, 1989, Socioeconomic status and obesity: A review of the literature, Psychological Bulletin, $105,260-275$.

[39] Tovee, M.J.,Furnham, A.\& Swami, V. Healthy body equals beautiful body? Changing perception of health and attractiveness with shifting socio-economic status. In : V. Swami and A. Furnham (eds), Body beautiful: Evolutionary and sociolcultural perspectives(pp.108-128). Basingstoke; Palgrave Macmillan, 2007.

[40] Singh, D, 1993, Waist-to-hip ratio (WHR): A defining morphological feature of health and female attractiveness. J. Personality and Social Psychology, 65(2), 293-307.

[41] Singh, D, 1993a, Adaptive significance of female physical attractiveness: Role of waist to hip ratio. Journal of Personality and Social Psychology,65, 293-307.

[42] Singh, D, 1993b, Body shape and women attractiveness: the critical role of waist to hip ratio. Human Nature,4, 297-321.

[43] Yu, D.W. \& Shepard Jr, G.H, 1998,Is beauty in the eye of beholder? Nature, 396, 321-322.

[44] Westman ,A.\& Marlow, F, 1999, How universal are preferences for female waist to hip ratios: Evidence from the Hadza of Tanzania. Evolution and Human Behaviour, 20, 219-228.

[45] Kaye, S.A., Folsom, A.R., Soler, J.T., Prineas, R.J. \& Potter, J.D, 1991, Associations of body mass and fat distribution withsex hormone concentrations in postmenopausal women. Int. J.Epidemiol., 20, 151-156.

[46] Singh, D, 1995, Female health, attractiveness, and desirability for relationships: Role of breast asymmetry and waist-to-hip ratio, Ethology and Sociobiology ,16, 465-481.

[47] de Waal, F, Chimpanzee politics: Power and sex among apes. London: Jonathan Cape, 1982.

[48] McGinnis, J. Selling of the President. New York. Penguin, 1988.

[49] Jencks, C., Inequality: A reassessment of thr effect of family and schooloing in America, Basic, New York, 1972.

[50] Udry, J.R, 1977, The importance of being beautiful. American Journal of Sociology, 83,154-160.

[51] Wang, F.F. \& Oakland, J, 1995, Qualities related to intelligence among Chinese children between ages 4-6. School Psychology International, 16, 59-65.

[52] Kasser, T. \& Sharma, Y.S, 1999, Reproductive freedom, educational equality, and females' preference for resource -acquistion characteristics in mates. Psychological Science, 10, 374-377.

[53] Todosijevic B, Ljubinkovic S and Arancic A ,2003, Mate selection criteria: A trait desirability assessment study of sex differences in Serbia. Evolutionary Psychology,11, 116-120.

[54] Ziegler, A., Kentenich, H., Uchanska-Ziegler, B, 2005, Female choice and the MHC. Trends Immunol. 26, 496-502.

[55] Neff, B.D., Pitcher, T.E, 2005, Genetic quality and sexual selection: an integrated framework for good genes and compatible genes. Mol. Ecol., 14, 19-38.

[56] Szalay, F.S., Costello, R.K, 1991, Evolution of permanent estrus displays in hominids. J. Human Evolution, 20, 439-464.

[57] Jasienska, G., Ziomkiewicz, A., Ellison, P. T., Lipson, S. F., \& Thune, I, 2004, Large breasts and narrow waists indicate high reproductive potential in women. Proceedings of the Biological Sciences, The Royal Society, 271, 1213-1217.

[58] Kohl, J. V., \& Francoeur, R,.The scent of Eros: Mysteries of odor in human sexuality. IUniverse, 2002.

[59] Buss, D.M.2002.Human mating strategies. SAMFUNDSOKOVOMEN NR 4:47-58.

[60] Buss, D.M. \& Schmitt, P, 1993, Sexual strategies theory: An evolutionary perspective on human mating. Psychological Review, 100, 204-232.

[61] Greiling, H. \& Buss, D.M,2000, Women's sexual strategies: The hidden dimension of extra pair mating. Personality and Individual Differences, 28,939-963.

[62] Oda, R. 2001, Sexual dimorphic mate preferences in Japan: An analysis of lonely hearts advertisements. Human Nature, 12,191-206.

[63] Geary, D.C. \& Flinn, M.V, 2001, Evolution of human parental behaviour and the human family. Parenting: Science and Practice, 1, 5-61.

[64] Fink, B. \& Penton-Voak, I, 2002, Evolutionary psychology of facial attractiveness. Current Directions of Psychological Sciences, 11, 154-158.

[65] Miller, G. F, How mate choice shaped human nature: a review of sexual selection and human evolution, In: Handbook of 
evolutionary psychology, Crawford, C.and D.L. Krebs9Eds.) pp87-129, Mahwah, New Jersey: Erlbaum,1998.

[66] Miller, L.C.,Putcha-Bhagavatula, A. ,\& Pedersen, W.C, 2002, Men's and women's mating preferences: Distinct evolutionary mechanisms? Current Directions in Psychological Science,11, 88-93.

[67] Geary, D.C., Vigil, J. \& Byrd-Craven, J.2004. Evolution of human mate choice. The Journal of sex Reasearch, 41(1), $27-42$.

[68] Cunningham, M.R., Druen, B.B.\& Barbee, A. P.. Angels, mentors and friends: trade-offs among evolutionary, social, and individual variables in physical appearance. In: J. A. Simpson and D. T. Kenrick (eds), Mahwah: Lawrence Erlabaum, 1997.

[69] Miller, G. F, Darwinian demographics of cultural production. Talk at the Human Behavior and Evolution Society Seventh Annual Meeting, U. C. Santa Barbara, 1995.

[70] Geary, D.C, Male, female: the evolution of human sex differences. Washington DC: American Psychological Association, 1998.

[71] Bereczkei, T. Voros, S., Gal, A., Bernath, L, 1997, Resources, attractiveness, family commitment; reproductive decision in human m,ate choice. Ethology, 103, 681-699

[72] Maisey, D.S., Vale, E.E.E., Cornelissen, P.L., Tovée, M.J. 1999 .Characteristics of male attractiveness for woman, Lancet, 353, 1500.

[73] Mueller, U., Mazur, A, 2001, Evidence of unconstrained directional selection for male tallness. Behav Ecol Sociobiol,
$50,302-311$

[74] Clutton-Brock, T, 2007, Sexual selection in males and females. Science, 318, 1882-1885.

[75] Chance, M.R.A, Social behavior and primate evolution. In M. F. A. Montagu (Ed.), Culture and the evolution of man (pp. 84-130). Oxford University Press, 1962.

[76] Fox, R, Alliance and constraint: Sexual selection in the evolution of human kinship systems. In ,B. Campbell (Ed.), Sexual selection and the descent of man, 1871-1971 (pp. 282-311). Chicago: Aldine Atherton, 1972.

[77] Parker, S. T, 1987, A sexual selection model for hominid evolution. Human Evolution, 2(3), 235-253.

[78] Alexander, R.D, 1971, The search for an evolutionary philosophy of man. Proc. Royal Society of Victoria 84(1), 99-120.

[79] Caspari, E, 1972, Sexual selection in human evolution. In ,B. Campbell (Ed.), Sexual selection and the descent of man (pp. 87-104). Chicago: Aldine.

[80] Kokko, H., Brooks, R., Jennions, M.D., Morley, J.2003,The evolution of mate choice and mating biases. Proc. R. Soc. B. 270, 653-664.

[81] Birkhead, T.R., Kappeler, P.M,Postcopulatory sexual selection in birds and primates. Pp. 151-172 in: Sexual Selection in Primates. Kappeler PM, van Schaik CP (eds). Cambridge: Cambridge University Press, 2004.

[82] Clutton-Brock, T.H. \& Parker, G. A, 1992, Potential reproductive rates and the operation of sexual selection. Q. Rev. Biol., 67, 437-456 